\title{
Schema-inhibitors of Happiness and their
}

\section{Remediation}

\author{
contribution to Positive Psychotherapy Jiri Kulka
}

\section{ABSTRACT}

The author describes his own concept of happiness, which he has derived from an original theory of personality. Personality structure consists of four subsystems: motivational, executive, egotic, and character. The definition of happiness as a synergic unity of joy, bliss, self-actualization, and meaning comes from the concept of saturation of these personality substructures. Further he focuses on factors which hinder life happiness and shows the possibility to implement schema therapy in the area of positive psychotherapy. Both therapeutic systems can be interconnected in the following manner; that is we can use schemas (Young et al.) to explain the origin of conflicts (Peseschkian).

KEY WORDS: happiness; structure of personality; motivational, executive, egotic, and character subsystem; joy, bliss, self-realization, sense/meaning; schema therapy; positive psychotherapy

\section{INTRODUCTION}

There are many possibilities of how to define psychotherapy. One of them is to qualify it as assisting people to strive towards life happiness. In this case we first need to comprehend what happiness is, and what it can denote for a person, in general.

In literature we find a number of attempts to psychologically define "happiness". Its definition continues to evolve (see Veenhoven 2008: World Database of Happiness, or, for example Diener 2000, Seligman, Csikszentmihályi 2000, Nakamura, Csikszentmihalyi 2002, Keyes, Haidt 2003, Seligman 2011). We also highly value the theories of H. Gardner, M. Csikszentmihalyi and W. Damon (2001), M. E. P. Seligman (2002), L. G Aspinwall and U. M. Staudinger 2003, P. A. Linley and S. Joseph (2004), Ed. Diener (2008), Ch. Peterson and M. E. P. Seligman (2004), A. M. Wood and N. Tarriera (2010) et al.

In the past 20 years we have developed our own theory of personality and happiness at the ARCANA institute. Personality and happiness form a relationship - experiences of happiness have an affinity towards the individual personality substructures. Our original results are quite similar to Seligman's initial conception, but based on different premises, however.

\section{INITIAL QUESTIONS}

A psychological definition of "happiness" is very difficult since it represents a rather subjective concept. Life happiness is experienced differently by various individuals. That is why it is important to find such a conception that will allow the inclusion of all possible individual experiences. In view of the lack of a unified and satisfactory definition in the present literature, which often overlaps with terms such as quality of life, satisfaction with life, wellness, well-being, welfare, happiness, and flourishing, we draw on our own conception, which we introduce through these simple questions:

1) how happiness can be understood, 
2) how it can be derived from the theory of personality,

3) what are the inhibitors of happiness, and

4) how can we work with these inhibitors in psychotherapy.

We are carrying on from our research which was collected over twenty years; its conclusions were clinically verified in practical therapy. Even though we have reviewed a great number of reports from other authors, we will mention only the most closely connected ones so that we can better outline the context of our reasoning.

\section{THEORY H}

„Happiness" is a very frequent topic in current positive psychology, but there is no stable conception of it as is shown in the publications of M. Seligman (2011) and his co-workers. The definitions of happiness are being changed and it seems that hitherto no satisfactory conception has been found. We believe the main cause is that theories of happiness are not built on a generally acceptable theory of personality. The meaning of happiness was most often discussed on a philosophical level or based on the quite empirical opinions of people.

We have derived the concept of happiness from the theory of personality (Kulka, 1987, 2009, 2012). Then, happiness was defined as a state of joy, bliss, self-fulfillment, and meaning. Joy is a feeling of accomplishment. The opposite of joy is disappointment. Bliss is a state of physical and mental delight which is beneficial to us. Self-fulfillment is a state where an individual is self-actualized, and there is nothing that lacks. Meaningfulness is a state of understanding and comprehending the purposefulness of life.

Here there is the schema of happiness:

\section{Self-fulfillment}

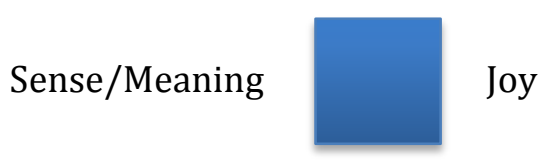

Bliss

The proposed model is not only simple, but, above all, it meets the requirement for the possibility of subjective fulfillment of individual categories. That is, for example, an emotion of joy can follow any activity whose successful completion causes joy. Additionally, experiences of bliss can accompany various possible pleasant physical or mental acts. Specific self-actualization always depends on the personality predispositions of an individual, so one can feel fulfilled through maintaining a well-tended garden just as well as through winning a Nobel Prize. And finally, meaningfulness is understood here as very closely tied to the unique fate of an individual, which could be operationalized through set life goals. It is not therefore important "what meaning our life has" or "where we came from and where we are headed", but for instance a meaningful life fulfillment through offspring or creative work. It is easy to glimpse that the individual dimensions of happiness overlap, which, by the way, is given also due to their synergy. 


\section{SYSTEM THEORY OF PERSONALITY}

Our theory of personality is based on the systems theory (Kulka, 2007). It stems from a simple schema: needaction. Thus we postulated a motivational subsystem and an executive subsystem. They are, of course, related to Ego/Self, and the whole structure of personality is described as character. The block-schema follows:

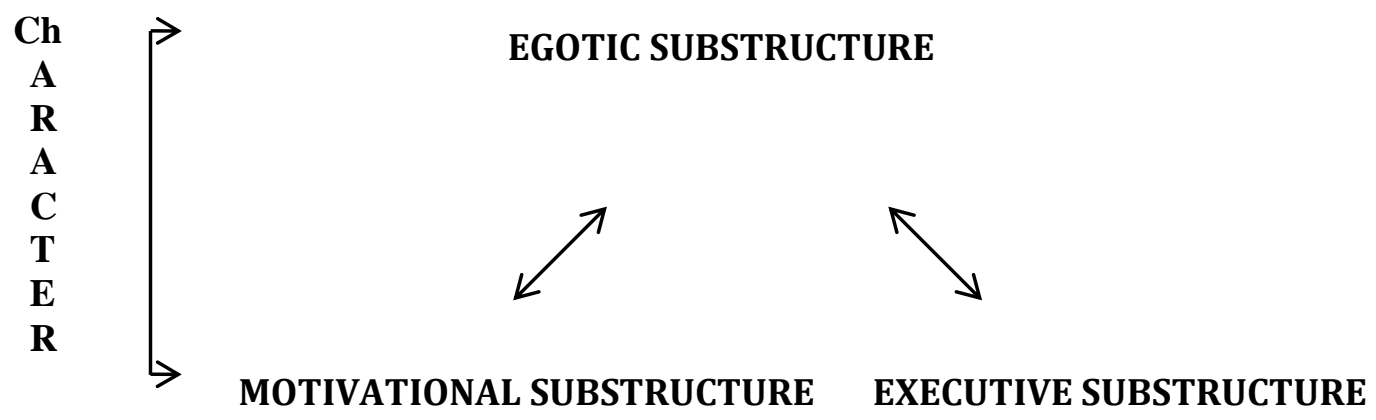

This "Cartesian" theory (I need, therefore I act) is first described and discussed in a publication by the author of the article (Kulka, 1987). Again it is not possible to consider isolated structures, but it is necessary to keep in mind their interplay and intersecting: synergy. Two "higher" substructures deserve closer explanation. The egotic personality subsystem serves as a "center of functioning" (Piaget's concept, see 1970). At the same time, however, it integrates other parts of personality, which were described for example by H. Kohut (1977) in his Self psychology. The character subsystem constitutes the highest integration of personality, which represents personality as a whole. Let us take for example a complex trait like diligence. It is obvious that a diligent man is positively motivated, has certain executive dispositions towards work, which is his self-actualization. This whole complex is then one of the substantial parts of character.

We can put the two theories into a close relationship as follows:

\section{Self-fulfillment}

Egotic sbs.

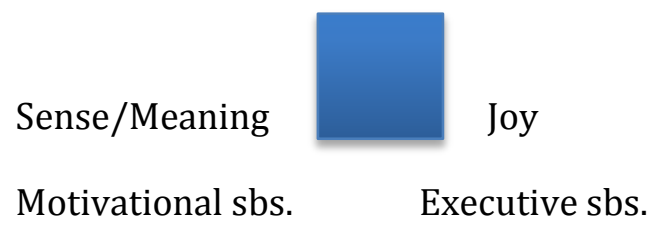

Bliss

Character sbs. 


\section{INHIBITORS OF HAPPINESS}

Now, what are the inhibitors of happiness? We call them psychological problems, which can be defined as „not having skilled adaptive responses or solutions to current/passing situations". Skillful adaptive responses are understood as behaviors, which lead to dealing with a given situation (effectively). Even such difficult situations as, for example, a diagnosis of cancer or the state after a devastating natural disaster can be, after the temporary anxiety or depressive reaction passes, dealt or managed. There are accounts of people who had a disabled child and this unlucky turn of events lifted them spiritually; others lost their jobs and after mobilizing their resources found even better ones, etc. Recently there has been quite a lot of research on the influence of psychotrauma on further (positive) personal(ity) growth (e.g. see Vaillant, 2006, Joseph, Linley 2008, Mareš 2012 etc.).

In our opinion there are three kinds of psychological problems:
a) frustration,
b) conflict, and
c) stress.

These problems can be coped with succesfully, but, on the other hand, they can become psychotraumas, especially if they are of high degree or duration. We differentiate macrotraumas and microtraumas. Single microtraumas - i.e. everyday small frustrations or conflicts, or not very intensive stress - may not have a serious effect, but if they acumulate, they can lead to psychological disorders (Pesseschkian, 1987).

What is the mechanism for the onset of pathological symptoms?

Generally, people approach and perceive their reality in repetitious ways. They also organize their experience to make sense of their life. Organizing principles of experience are often called "cognitive schemas“. The schema construct has a relatively long history. We follow up on the theory of schema therapy.

J. E. Young, J. S. Klosko and M. E. Weishaar (2003, p. 20) have defined an „Early Maladaptive Schema“ as a „broad, pervasive theme or pattern comprised of memories, emotions, cognitions, and bodily sensations... dysfunctional to a significant degree". They described 18 main schemas, which are triggered in adulthood by life events that people - often unconsciously - perceive as similar to the traumatic experiences of their childhood. ${ }^{4}$

However, not all schemas are based on childhood trauma or mistreatment. They can also be caused by later noxious experiences that are repeated. In our opinion, these early maladaptive schemas are the main inhibitors of experiencing happiness. Furthermore, we can add to this serious psychological problems of life, especially a lack of self-realisation and an understanding of sense/meaning.

Ed. Diener and R. Biswas-Diener (2008) mean that rather than viewing happiness as a pleasant or peaceful state of mind, happiness is helpful and functional, it is a resource to be used rather than only to be enjoyed. Their research showed that happy people live longer, succumb to fewer illnesses, stay married longer, commit fewer crimes, produce more creative ideas, work harder and better on the job, make more money, and help others more.

\footnotetext{
${ }^{1}$ In the Czech Republic and Slovakia, the following experts (among others) draw on the knowledge of and experience with SFT - J. Praško, M. Šlepecký and J. Kordačová, who had presented them at CBT conferences (see also Praško, Možný, Šlepecký et al, 2007, Kordačová 2013a, b). Thanks to them we started considering their use in positive system psychotherapy as well.
} 
Young, Klosko and Weishaar classified the schemas in 5 categories:

Domain I: Disconnection and Rejection (the client is unable to form satisfying attachments to others)

Schemas: abandonment/instability, mistrust/abuse, emotional deprivation, defectiveness/shame, social isolation/alienation

Domain II: Impaired Autonomy and Performance (the client is unable to separate himself from his family)

Schemas: dependence/incompetence, vulnerability to harm or illness, enmeshment/undeveloped self, failure

Domain III: Impaired Limits (the client has not developed adequate internal limits in regard to reciprocity or selfdiscipline)

Schemas: entitlement/grandiosity, insufficient self-control/self-discipline

Domain IV: Other-Directedness (the client places an excessive emphasis on meeting the needs of others rather than his/her own needs)

Schemas: subjugation, self-sacrifice, approval-seeking/recognition-seeking

Domain V: Overvigilance and Inhibition (the client suppresses his/her spontaneous feelings and impulses)

Schemas: negativity/pessimism, emotional inhibition, unrelenting standards/hypercriticalness, punitiveness

A basic view of the authors is that schemas result from unmet core emotional needs in childhood. The list of needs is as follows:

1. Secure attachment to others (includes safety, stability, nurturance, and acceptance)

2. Autonomy, competence, and sense of identity

3. Freedom to express valid needs and emotions

4. Spontaneity and play

5. Realistic limits and self-control“ (i.d., p. 23)

The goal of schema therapy is to help clients find adaptive ways to meet their core emotional needs.

If we take into consideration various stages of development and aging, one could argue that the successful resolution of each stage results in an adaptive schema, whereas the failure to resolve a stage leads to maladaptive schema.

Clients develop maladapive coping styles and responses early in life in order to adapt to schemas, so that they do not have to experience negative emotions. Coping styles are manifested through cognition, affect, or behavior. They are not part of the schemas themselves.

Young et al. (2003) differentiated three schema coping styles which correspond to three basic responses to threat - overcompensation (fight), avoidance (flight), and surrender (freeze). 
Coping styles are expressed through specific behaviors called coping responses. And current active schemas and responses of an individual are called - Schema Modes.

The modes were grouped into four general categories: child modes, dysfunctional coping modes, dysfunctional parent modes, and the healthy adult mode. „One important goal of schema therapy is to teach patients how to strengthen their Healthy Adult Modes, so that they can learn to navigate, negotiate with, nurture, or neutralize dysfunctional modes." (Young et al., p. 53) Schemas and behavior modes are also more closely described in the publication of J. Praško, P. Možný, M. Šlepecký et al. (2007, p. 59 ad.) and in the review study of J. Kordačová (2013b, p. 562 ad.).

\section{POSITIVE SYSTEM PSYCHOTHERAPY}

Positive psychotherapy keeps developing as well. Our positive system psychotherapy (PSP) follows the positive psychotherapy of N. Peseschkian, which was created in the sixties and seventies of the last century. PSP is based on general systems theory and includes some knowledge from positive psychology. We have worked out System Theory of Personality and Theory H (happiness).

Measuring experiences of happiness is important for both diagnostics and psychotherapy. A number of questionnaires and inventories were designed for that purpose (see Lopez, Snyder, 2006, Ong, Dulmen 2007, or Ryff, 1995: method „Psychological Well-Being Scale“, Lyubomirsky, Lepper, 1999: method „Subjective Happiness Scale“, Hills, Argyle, 2002: method „Oxford Happiness Questionnaire“, Jackson, Eklund 2004: method „Flow“, Peterson, Park, Seligman, 2005: method „Orientation to Happiness“, Hecktner, Schmidt, Csikszentmihalyi 2007: method „Flow“, Diener, Wirtz, Tov, Kim-Prieto, Choi, Oishi, Biswas-Diener 2009: method „Flourishing Scale"). For the most part they seem to us to be too short or not specific enough. Furthermore, the application of psychometric standards based on statistical data is questionable here. Qualitative approaches and methods seem more appropriate/suitable.

In order to increase construct validity and, last but not the least, in order to guarantee continuity with the above described theory we have also constructed the questionnaire IHAB (Inventory of Happiness, forms A, B; full version is available at www.arcana.cz), which measures experiencing happiness. Clients with different diagnosis perceive and experience their life happiness in diferent ways as is shown on the following graphs, for instance:

Schizoid personality disorder (client - F, 30 yrs, high school ed.):

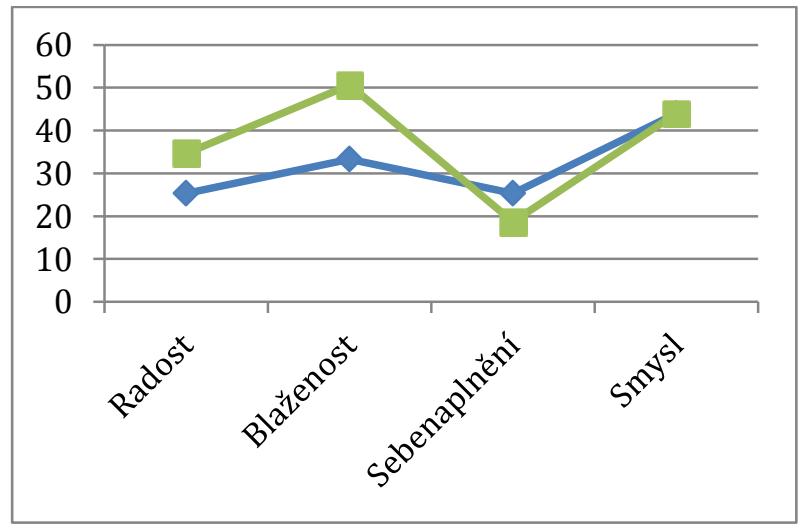

(radost -joy, blaženost -bliss, sebenaplnění -self-fulfillment, smysl -sense; upper line = habitual happiness, lower line $=$ actual happiness) 
Paranoid schizophrenia (client - M, 33 yrs, high school ed.):

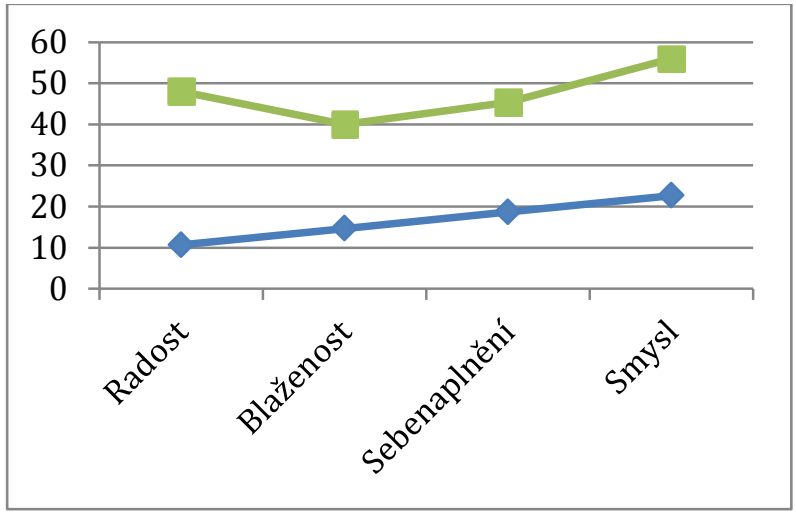

(radost -joy, blaženost -bliss, sebenaplnění -self-fulfillment, smysl -sense; upper line = habitual happiness, lower line $=$ actual happines)

These are only typical examples. Given diagnoses cannot be fully represented by them. However, further possibilities to apply the inventory and also the options/potential of refining diagnostic results in practice are shown.

In a normal population the four dimensions of happiness (IHAB) are situated over $80 \%$ and very often over $90 \%$. Clients with various disorders fall under $60 \%$ and very often under $40 \%$. Besides, it was found that perceiving and sensing happiness strongly varies interindividually.

According to Young, Klosko and Weishaar $(2003,2005)$ therapist should ally with clients in fighting their schemas, utilizing cognitive, affective, behavioral, and interpersonal strategies. When clients repeat dysfunctional patterns based on their schemas, the therapist should empathically confront them with the reasons for change. Through "limited re-parenting" the therapist supplies many clients with a partial antidote to the needs that were not adequately met in childhood.

According to N. Peseschkian (1987, 2000) it is necessary, using differentiation analysis, to solve intra- and interpersonal conflicts in the following areas: Punctuality, Cleanliness, Orderliness, Obedience, Courtesy, Honesty/Candour, Faithfulness, Justice, Diligence/Achievement, Thrift, Reliability/ Conscientiousness, Love, Patience, Time, Trust/Hope, Contact, Sex/Sexuality, and Faith/Religion). „The capacity to differentiate is the basis for all these functions. They acquire their degree of differentiation through learning experiences. The therapeutic intervention, regardless of which method is applied in each individual case, is, in the last analysis, an attempt to make it possible for the patient to make more refined discriminations which are suited to the situation and which enable him to behave appropriately in the face of the demands of a situation, within the framework of his projected aims. The expression „differentiation analysis" makes this clear from the outset." (1987, pp. 45-46).

It is possible to say that the above-mentioned schemas are behind the conflicts, in which patients become involved. Due to the rigid application of their schema, they are not able to act adequately. The schemas can be used for explanations of why the conflicts arise. The following vignettes can illustrate it:

Vignette 1) 
A young man works in a family company, which is directed by his father. He feels like a member of management. However, he often gets into conflicts with their accountant, who feels like an important part of the company and who behaves dominantly. The Schema of Grandiosity had been identified in the man, and therefore he cannot appropriately communicate with the accountant, who often gets upset. Previously, he brought a new employee into the company. The accountant, however, did not like him and let it clearly be known. She asked him whether his father knew about the new employee. The young man felt offended and a conflict arose which he was not able to deal with assertively (he did not say anything). Subsequently, his psychosomatic problems (GIT) got significantly worse, with stomach ache being the main symptom. Beyond the conflict, pertaining to Respect and Obedience, hides the Schema of Entitlement/Grandiosity. If the schema had not been there, he might have, for example, told the accountant that it was none of her business and that it would be better if she focused on her job, or he might have told her less harshly that he had already discussed it with his father. That client is being treated for psychosomatic problems.

\section{Vignette 2)}

A middle-aged teacher works at an elementary school. She keeps getting into conflicts with the students' parents, at home with her husband, and with her adult children. During her childhood a complex of abandonment developed, so she tried to obtain her parents' love through for example good grades at school. At present she finds herself unable to openly tell the students' parents what she would like to (Conflict Courtesy/Candour) and also at home she experiences conflicts with her husband who often ignores her wishes. The latest conflict arose when she asked her husband to have their car washed and he refused. She was able to accept that. However, when he came two days later saying that he was planning to have the car washed for the reason that he was planning to have it serviced, she broke down and started crying. She interpreted it as fact that her husband was more concerned about what other people thought, that their opinions were more important than hers, and that he was always leaving her out/ignoring her. In this case the Schema Abandonment/Instability is hiding beyond the Conflict of Love and Justice. The client suffers from massive anxiety and currently avoids people.

The goal of treatment in positive system psychotherapy is

1) to increase the clients's conscious control over schemas and to weaken them,

2) to show the client's psychological reserves and perspectives, and

3) to aid him in being more happy (finding his own way to happiness)

\section{CONCLUSION}

We consider the term "happiness" to be in agreement with spiritual authorities like, for example, Dalai Lama XIV (1999), the highest goal of human life. We believe that one of the most important tasks of psychology, psychiatry and psychotherapy is to help people find their own path to happiness.

Thus, positive system psychotherapy is oriented not only on sick people but also on clients who are interested in striving towards increased happiness, in broadening and deepening their spiritual life.

An advantage of this school/system of psychotherapy is, that it can contain any current or future inspirations from other schools/systems, which are in agreement with any attempts at integration of contemporary psychotherapy. We have shown here that the use of schema therapy works hand-in-hand with positive psychotherapy, which we have furthermore enriched with a system theory, personality theory and theory $\mathrm{H}$. 


\section{REFERENCES}

Aspinwall, L. G., Staudinger, U. M. (Eds.). (2003). A psychology of human strengths: Fundamental questions and future directions for a positive psychology. Washington, DC: American Psychological Association.

Dalajlama, jeho svatost a Cutler, H. C. (1999). Cesta ke štěstí. Průvodce dobrým životem. Praha: PRAGMA.

Diener, E. (2000). Subjective well-being: The science of happiness and a proposal for a national index. American Psychologist, 55, 34-43.

Diener, Ed., Biswas-Diener, R. (2008 ). Happiness: Unlocking the Mysteries of Psychological Wealth. Malden, Oxford, Carlton: Blackwell Publishing.

Diener, E., Wirtz, D., Tov, W., Kim-Prieto, C., Choi, D., Oishi, S., Biswas-Diener, R. (2009). New measures of wellbeing: Flourishing and positive and negative feelings. In: Diener, E. (ed.). The Collected Works of Ed Diener, vol. 3, 247-266, Dordrecht, NL: Springer.

Gardner, H., Csikszentmihalyi, M., Damon, W. (2001). Good work: When excellence and ethics meet. New York: Basic Books.

Hecktner, J. M., Schmidt, J. A., Csikszentmihalyi, M. (2007). Experience Sampling Method. Measuring the Duality of Everyday Life. Thousand Oaks: Sage Publications.

Hills, P., Argyle, M. (2002). The Oxford Happiness Questionnaire: a compact scale for the measurement of psychological well-being. Personality and Individual Differences. 33, 7, 1073-1082.

Jackson, S. A., Eklund, R. C. (2004). The Flow Scales Manual. Morgantown: Fitness Information Technology.

Joseph, S., Linley, P. A., eds. (2008). Trauma, recovery and growth. Positive psychological perspectives on posttraumatic stress. New Jersey, Hoboken: John Wiley \&Sons.

Keyes, C. L. M., Haidt, J. (Eds.). (2003). Flourishing: Positive psychology and the life well lived. Washington DC: American Psychological Association.

Kohut, H. (1977). The Restoration of the Self. New York: International Universities Press, Inc.

Kordačová, J. (2013a). Pozitívna psychológia - nádej pre maladaptívne schémy? Referát na 2. Mezinárodní konferenci pozitivní psychologie v České republice. Kniha abstraktů. Brno: CPPC, s. 44.

Kordačová, J. (2013b). Schémy na rozhraní kognitívnej, klinickej a pozitívnej psychológie. Československá psychologie, 57, 6, 554-568.

Kulka, J. (1987). - Zvláštnosti osobnosti mladých umělců. In: Světový názor a umělec socialistické epochy. Ed. J. Kulka, JAMU, Brno, 137 - 176.

Kulka, J. (2007). Systémová teorie osobnosti pro psychoterapii. Psychiatria, psychoterapia, psychosomatika, 14/2-3, 121-126.

Kulka, J. (2009). Teorie H. Psychiatria, psychoterapia, psychosomatika, 16/1, 43 - 49.

Kulka, J. (2012). Osobnost, štěstí, umění. Psychologie a její kontexty, 3/2, 109 - 130. 
Linley, P. A., Joseph, S. (Eds.). (2004). Positive psychology in practice. New Jersey, Hoboken: John Wiley \&Sons.

Lopez, S. J., Snyder, C. R. (eds.) (2006). Positive Psychological Assessment. A Handbook of Models and Measures. Washington, DC: APA.

Lyubomirsky, S., Lepper, H. S. (1999). A measure of subjective happiness: Preliminary reliability and construct validation. Social Indictors Research. 46, 137-155.

Mareš, J. (2012). Posttraumatický rozvoj člověka. Praha: GRADA.

Nakamura, J., Csikszentmihalyi, M. (2002). The concept of flow. In Snyder, C. R. , Lopez, S. J., eds., (2002). Handbook of Positive Psychology. New York: Oxford University Press, 89-105.

Ong, A. D., Dulmen, M. H. M. (2007). Oxford Handbook of Methods in Positive Psychology. New York: Oxford University Press.

Peseschkian, N. (1987). Positive Psychotherapy. Theory and Practice of a New Method. Berlin, Heidelberg: Springer.

Peseschkian, N. (2000). Psychosomatik und Positive Psychotherapie. Frankfurt am Main: Fischer Taschenbuch Verlag GmbH.

Peterson, Ch., Park, N., Seligman, M. E. P. (2005). Orientations to happiness and life satisfaction: The full life versus the empty life. Journal of Happiness Studies, 6, 25-41.

Peterson, Ch., Seligman, M. E. P. (2004). Character strengths and virtues: A handbook and classification. Washington-Verlag.

Piaget, J. (1970). Structuralism. New York: Harper \& Row.

Praško, J., Možný, P., Šlepecký, a kol. (2007). Kognitivně behaviorální terapie psychických poruch. Praha/Kroměříž: TRITON.

Ryff, C. D. (1995). Psychological well-being in adult life. Current directions in Psychological Science, 4, 99-104.

Seligman, M. E. P. (2011). Flourish: A Visionary New Understanding of Happiness and Well-being. New York: Free Press.

Seligman, M. E. P. (2002). Authentic happiness. New York: Free Press.

Seligman, M. E. P., Csikszentmihalyi, M. (2000). Positive Psychology. An Introduction. American Psychologist, vol. $55,1,5-14$.

Vaillant, G. E. (2000). Adaptive mental mechanisms: Their role in a positive psychology. American Psychologist, $55,89-98$.

Veenhoven R. (2014). World Database of Happiness, Bibliography. Internetsite: worlddatabaseofhappiness.eur.nl.

Wood, A. M., Tarrier, N. (2010). Positive Clinical Psychology: A new vision and strategy for integrated reasearch and practice. Clinical Psychology Review, 30, 819-829. 
Young, J. E. (2005). Schema-focused cognitive therapy and the case of Ms. S. Journal of Psychotherapy Integration, $15(1), 115-126$.

Young, J. E., Klosko, J. S., Weishaar, E. (2003). Schema therapy. A Practitioner's Guide. New York, London: The Guilford Press.

Doc. PhDr. Mgr. et Mgr. Jiří Kulka, CSc.,

director of the Institute for Positive System Psychotherapy ARCANA, Brno

kulka@arcana.cz,jkulka50@icloud.com

Doručeno redakční radě 10. 10. 2013

Přijato po recenzi 12. 3. 2014 